\title{
IEEE SENSORS 2013 (12th IEEE SENSORS conference) 報告
}

正員 式田 光宏 (名古屋大学)

\section{1. はじめに}

第 12 回 IEEE SENSORS 国際会議が 11 月 3 日（日）か ら 6 日（水）までの 4 日間の日程でアメリカ, ボルチモア にて開催された。本会議は，センサデバイスのみならず信 号処理回路およびセンサ応用まで網羅する会議として位置 づけられる。

\section{2. 会議概要}

参加者数, 応募件数, 採択論文数などは以下の通り。

（1）参加者数: $700 \sim 800$ 人

参加者は前回の台北開催（650～700 人）に比べわずかに 増加した。

（2）論文応募件数：913 件

論文数は前回（1080 件）に比べ 1 割ほど減少した。採択 論文数は 492 件（Late news を含まず）となり，採択率は $54 \%$ ある（採択率は前回と同じ）。国別論文数順位は, (1)アメリカ, (2)中国, (3)ドイツ, (4)日本, (5)イタリアとなっ ている。昨年度は, (1)台湾, (2)アメリカ, (3)日本となって おり，本会議開催に対して開催国が力を入れる傾向がある。 また本会議における中国の論文数が着実に増加している。 なお，今年度，日本は，日程的に「センサ・マイクロマシ ンと応用システム」シンポジウム（仙台開催）と重なり， 発表および参加者数ともに少ないように感じた。

（3）発表論文分野

本会議が対象とする分野は下記の 9 つである。

(1) Phenomena, Modeling and Evaluation

(2) Chemical and Gas Sensors

(3) Biosensors

(4) Optical Sensors

(5) Mechanical, Magnetic, and Physical Sensors

(6) Sensor / Actuator Systems

(7) Sensor Networks

(8) Applications

(9) Other Sensor Topics - Materials, Process, Circuits, Signals \& Interface, etc

上記に示したように, 発表分野はデバイスからシステム 応用まで幅広くセンサ技術を網羅している。

（4）発表論文

発表論文は，口頭発表（252 件）と，ポスター（278 件）

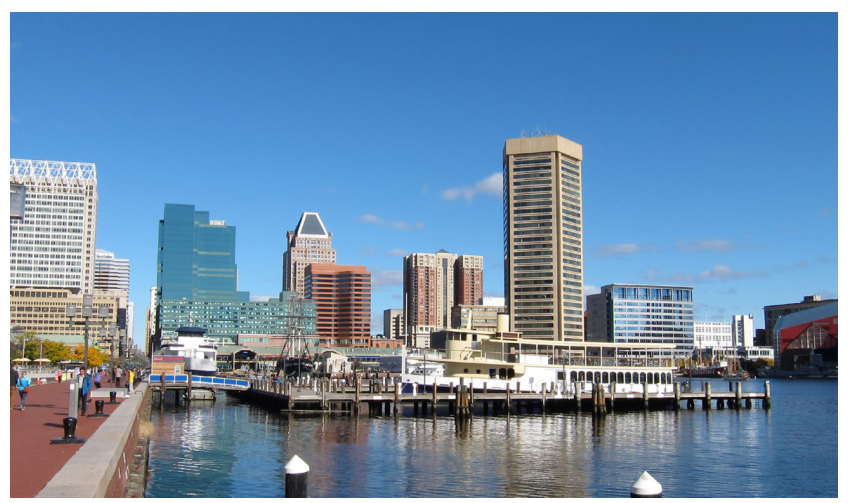

図 1 会議場及びその周辺

とで構成されており, 口頭発表の内訳は, キーノート : 3 件, 招待講演： 13 件,一般講演 : 236 件となっている。

キーノート 3 件は, 江刺先生 (東北大), Puers 先生 (ESAT-MICAS), Johnson 先生 (Monterey Bay Aquarium Research Institute）がそれぞれパッケージ技術，医療応用 技術，海洋におけるセンシング技術について解説した。

今回の会議において印象に残ったことを以下に示す。

まず一つ目は，2 日目の昼食時間に「Wearable Sensors： the Good, the Bad, and Alluring」と題した Industry Lunch Panel が開催されたことである。情報化の発展に伴いセンサ のウエアラブル化が急速に進展しており, これに着目した 集会である。アメリカにてすでにウエアラブルセンサを実 用化した 6 社の代表者からの自社製品の紹介とともに, ウエ アラブル化に対するパネルディスカッションが行われた。

二つ目の特記すべき点は, パラレルセッションに対する 扱いである。口頭発表が 6 つのパラレルセッションで行わ れるために, 講演者の発表内容が録音され, 会議後に, web サイトから無料で講演内容がダウンロードできるサービス が提供された。

\section{3. おわりに}

本会議はセンサに関する幅広い内容を提供する国際会議 である。次回は 2014 年 11 月 2 日から 5 日までバレンシア (スペイン) にて開催される予定である。詳細は下記 URL を参照していただきたい。

Conference web site: www.ieeesensors2014.org (平成 26 年 2 月 10 日受付) 